\title{
8
}
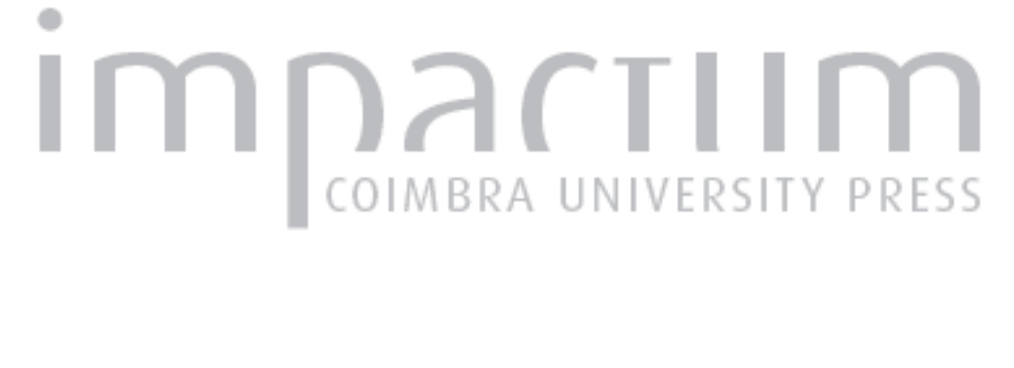

\section{Os fundamentos históricos e filosóficos do método hermenêutico da escola de Tübingen}

Autor(es): $\quad$ Oliveira, Anselmo Carvalho de Publicado por: Universidade Católica de Petrópolis; Instituto Brasileiro de Informação

URL

persistente:

URl:http://hdl.handle.net/10316.2/33045

DOI:

DOI:http://dx.doi.org/10.14195/1984-6754_3-1_1

Accessed : $\quad$ 26-Apr-2023 11:48:23

A navegação consulta e descarregamento dos títulos inseridos nas Bibliotecas Digitais UC Digitalis, UC Pombalina e UC Impactum, pressupõem a aceitação plena e sem reservas dos Termos e Condições de Uso destas Bibliotecas Digitais, disponíveis em https://digitalis.uc.pt/pt-pt/termos.

Conforme exposto nos referidos Termos e Condições de Uso, o descarregamento de títulos de acesso restrito requer uma licença válida de autorização devendo o utilizador aceder ao(s) documento(s) a partir de um endereço de IP da instituição detentora da supramencionada licença.

Ao utilizador é apenas permitido o descarregamento para uso pessoal, pelo que o emprego do(s) título(s) descarregado(s) para outro fim, designadamente comercial, carece de autorização do respetivo autor ou editor da obra.

Na medida em que todas as obras da UC Digitalis se encontram protegidas pelo Código do Direito de Autor e Direitos Conexos e demais legislação aplicável, toda a cópia, parcial ou total, deste documento, nos casos em que é legalmente admitida, deverá conter ou fazer-se acompanhar por este aviso.

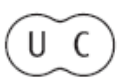



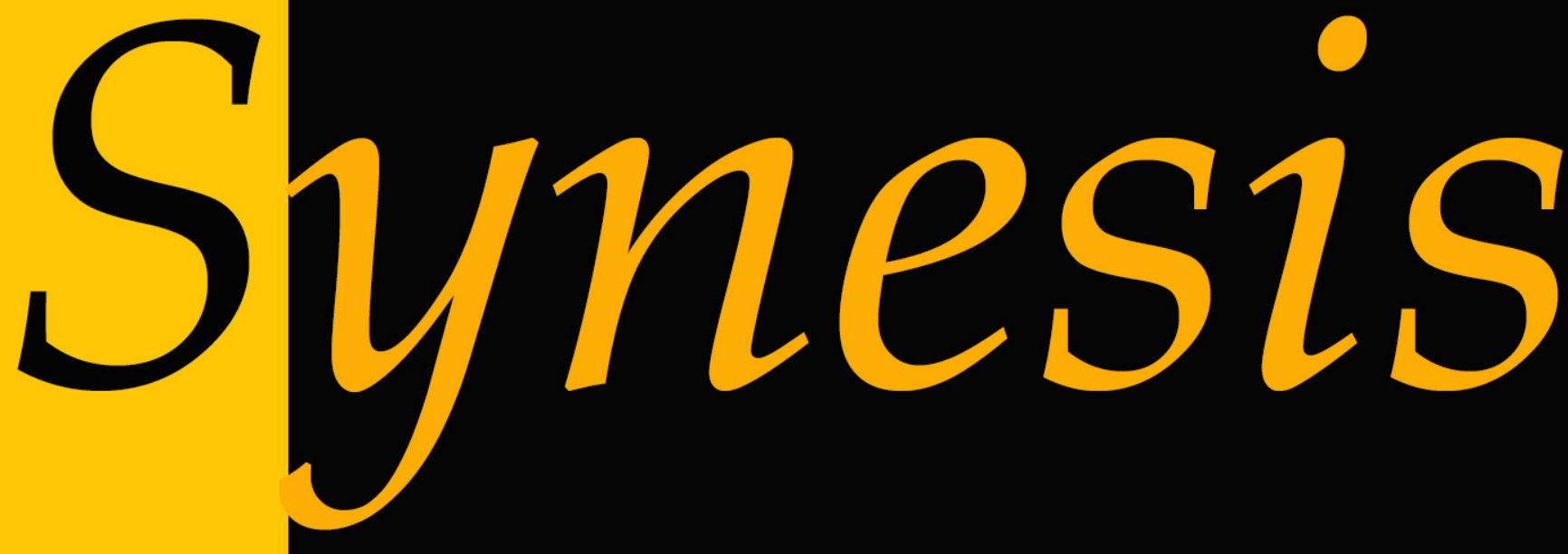

Revista do Centro de Teologia e Humanidades ISSN 1984-6754

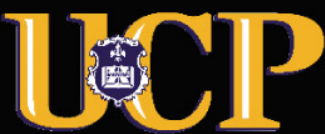




\title{
OS FUNDAMENTOS HISTÓRICOS E FILOSÓFICOS DO MÉTODO HERMENÊUTICO DA ESCOLA DE TÜBINGEN ${ }^{1}$
}

\author{
Anselmo Carvalho de Oliveira ${ }^{2}$
}

Resumo: $\mathrm{O}$ método de interpretação dos diálogos platônicos, na segunda metade do século XX, passou por uma profunda revisão levada a termo pela Escola de Tübingen, que culminou em um novo paradigma histórico-hermenêutico para a leitura dos diálogos. Platão, a partir do século XIX, foi interpretado à luz do método romântico proposto por Schleiermacher. Nesse método, considerava-se o texto como a expressão acabada de um pensamento. De Platão, excepcionalmente, possuímos todos os seus diálogos. Por consequência, podemos extrair de todos os seus diálogos, todo o seu pensamento. Para os autores de Tübingen, no entanto, esse método negligência os "autotestemunhos" presentes no Fedro e na Carta VII sobre o real valor da escrita na ótica platônica e relega ao segundo plano as ideias ouvidas na Academia e transmitidas pelos seus discípulos (os "ensinamentos náo-escritos"). Baseados nesses ensinamentos, os autores de Tübingen formularam um novo paradigma. O presente trabalho busca apresentar de forma sucinta as bases desse novo paradigma que vem causando acirrada polêmica entre os estudiosos do assunto.

Palavras-chave: Platão; Escola de Tübingen; Ensinamentos Não-escritos.

Abstract: The interpretation method of the Platonic's Dialogues, on the second half of the 20th Century, has suffered only a deep review carried by a done by Tübingen School that culminated in a new paradigm historical hermeneutic for the reading of Platonic's Dialogues. Plato, since the 19th Century, was interpretaded at the light of the romantic method proposed for Schleiermacher. In this method was considerated the text as an accomplished expression by one thought. From Plato, excepnally, we have one of his dialogues. Thus we can extract of his dialogues, all this thought. For Tübingen's authors, however, this method neglected the self testimonies present in Phaedrus and in the Seventh Letter about the real value from writting, in the foist of view and banish to the second plane ideas heard in the Academy and transmitted to his student's ("unwritten teaching"). Based on these teachings, the Tübigen's authors prescribed a new paradigm. The article search to show in a brief way the bases of this new paradigm that came causing a controversial polemic among the scholars of the subject.

Keywords: Plato; Tübingen School; Unwritten Teaching.

\footnotetext{
${ }^{1}$ Artigo recebido em 27/02/2011 e aprovado para publicação pelo Conselho Editorial em 29/05/2011.

2 Bolsista CAPES do Programa de Pós-Graduaçáo Stricto Sensu de Filosofia da Universidade Federal do Rio Grande do Norte (UFRN). Pós-Graduação Lato Sensu em Bioética pela Universidade Federal de Lavras (UFLA). Currículo Lattes: http://lattes.cnpq.br/8439304597935443. Email: anselmocarvalhooliveira@yahoo.com.br.
} 


\section{Introduçáo}

Platáo encontra-se no princípio da tradição metafísica ocidental. Os problemas filosóficos, quase todos, sejam lógicos, ontológicos, gnosiológicos, éticos e estéticos, possuem origem em seu pensamento. A importância do platonismo na cultura ocidental é um consenso entre os estudiosos (Cf. Santos, 1999, p. 12 e nota 14; p. 45 e nota 2; Reale, 2004, 112-113; Reale, 1994, p. 7-11, 323-332), mas o método com o qual se deve interpretá-lo causa profundas controvérsias.

$\mathrm{Na}$ segunda metade do século XX, o método de interpretação dos diálogos passou por uma profunda revisão promovida pelos estudiosos da Escola de Tübingen ${ }^{3}$ e culminou em um novo paradigma histórico-hermenêutico para a leitura dos escritos de Platão e, por consequência, de toda a sua filosofia. O paradigma tübingense $e^{4}$ é sustentado sobre a leitura dos "ensinamentos não-escritos"', i.é., os ensinamentos orais de Platáo no seio da Academia e transmitidos pelos seus discípulos, sobretudo Aristóteles e os primeiros acadêmicos. O conhecimento do novo paradigma é fundamental para a nova visão da filosofia platônica na contemporaneidade, pois ele determinará os problemas a serem resolvidos pelos pesquisadores e suas soluções modelares ${ }^{6}$.

\footnotetext{
${ }^{3}$ A escola, a partir da metade dos anos noventa, passou a ser chamada de Escola de Tübingen-Miláo devido aos importantes desenvolvimentos promovidos pelo estudioso italiano Giovanni Reale e seus colaboradores do paradigma proposto pelos tübingenses.

${ }^{4}$ As principais obras referentes ao novo paradigma são: Krämer, Arete bei Platon und Aristoteles. Zum Wesen und Geschichte der platonischen Ontologie, Heidelberg, 1959. Gaiser, Platons ungeschriebene Lehre. Studien zur systematischen und geschichtlichen Begründung der Wissenschaften in der Platonischen Schule. Neste livro encontra-se uma importante compilaçáo dos "ensinamentos não-escritos" de Platáo que foram transmitidos pela tradição indireta e chegaram até nós: Anhang: Testimonia Platonica. Quellentext zur Schule und mündlichen Lehre Platons, Stuttgart, 1963. Szlézak, Platon und die Schriftlichkeit der Philosophie. Interpretationen zu den frühen und mittleren Dialogen, Berlim, 1985. Reale, Per una nuova interpretazione di Platone. Rilettura della metafisica dei grandi dialoghi allá luce delle "Dottrine non scritte", Miláo, 1986, 1994. Remeto a esse livro para toda a discussão acerca da Escola de Tübingen e para uma bibliografia sistemática sobre o assunto.

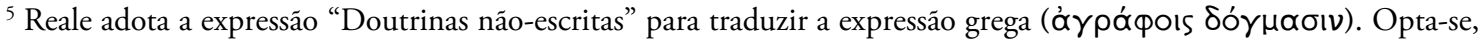
nesse texto, por traduzir a expressão por "ensinamentos não-escritos", para evitar, como pretendem os tübingenses, a sistematizaçāo do pensamento de Platáo, pois a "existência de qualquer Doutrina supóe o dogmatismo filosófico" (Matos, p. 1464). A tradução adotada aqui é cotejada com a versão francesa de Carteron da Física de Aristóteles, na qual se encontra a expressão.

${ }^{6} \mathrm{Na}$ epistemologia de Kuhn, seguida amplamente por Reale, o paradigma determina o critério segundo o qual os problemas científicos são propostos e suas possíveis soluçôes: "No intervalo, entretanto, durante o qual o paradigma foi bem-sucedido, os membros da profissão terão resolvido problemas que mal poderiam ter imaginado e cuja solução nunca teriam empreendido sem o comprometimento com o paradigma" (Kuhn, 1987, p. 45). Para interpretação de Reale da estrutura das revoluçôes científicas e sua aplicação ao paradigma da Escola de Tübingen confira 2004, p. 3-22.
} 
O presente trabalho apresenta a fundamentação histórica e teórica do novo paradigma e suas consequências no âmbito de uma renovadora interpretação da filosofia platônica. Não é propósito deste texto tratar da interpretação dos fundamentos textuais e das consequências epistemológicas das liçóes doutrinais de Platão.

\section{Os Três Paradigmas Anteriores na Interpretação de Platão}

A história das interpretações do pensamento de Platão inicia-se com os seus discípulos, no seio da Academia. Seus desenvolvimentos teoréticos e históricos encontram-se, principalmente, na Metafísica de Aristóteles. Os testemunhos de Espeusipo e Xenócrates, o segundo e terceiro escolarcas da Academia, também, são fundamentais para a reconstrução do platonismo.

Segundo Aristóteles, Platão afirmava que as coisas sensíveis estão em constante mudança e, portanto, a "definição" e o "universal" não se referem a nenhum objeto sensível e deles não é possível se fazer ciência. Mas existem “outras realidades” nas quais aquelas existem por participação e às quais são atribuídas as "definiçóes". Essas realidades, que fundamentavam e transcendiam o sensível, Platão as chamava de Ideias ou Formas (eíסos) (Metafísica, A6, 987a30987b10).

Em conexão com as Ideias, mas sem se identificarem totalmente com elas, existem os Números Ideais. Os Números Ideais, como os estudiosos notaram, possuem status metafísico e são a essência dos números matemáticos comuns, dos quais diferem. Consequentemente, não podem ser submetidos às operaçóes aritméticas. Segundo Reale (1994, p. 94), os Números Ideais são os primeiros a serem gerados, porque, paradigmaticamente, eles representam "a estrutura sintética de unidade-na-multiplicidade", que é a característica determinante dos planos do real. A determinação e delimitação do Uno sobre a Díade indeterminada são a sua essência. Por sua vez, entre as Ideias e a realidade sensível, em uma posiçáo ontológica intermediária, existe o plano dos Entes Matemáticos. Possuem um status intermediário, porque são “imóveis" e "eternos": a ciência da aritmética e da geometria podem fazer afirmaçóes somente sobre o inteligível; mas eles diferem das Ideias, porque existem muitos números, figuras geométricas e operaçóes matemáticas iguais, enquanto cada Ideia é "uma” e "indivisa” (Metafísica, A6, 87b10 ss). 
Platão, no entanto, não considerava as Ideias como as causas primeiras e definitivas dos seres. As Ideias e os Números Ideais participam, por derivação, da Díade de grande-e-pequeno no Uno. Aos dois princípios estruturais da realidade, Platão atribuía valor axiológico: o Uno era a causa do bem; a Díade, causa do mal.

\begin{abstract}
Do que dissemos, fica claro que ele [Platão] recorreu a apenas duas causas: a formal e a material. De fato, as Ideias são causas formais das outras coisas, e o Um é causa formal das Ideias. E à pergunta sobre qual é a matéria que tem a funçáo de substrato do qual se predicam as Ideias - no âmbito dos sensíveis -, e do qual se predica o Um - no âmbito da Ideias -, ele responde que é a díade isto é, o grande e o pequeno. Platão, ademais, atribui a causa do bem ao primeiro de seus elementos e a causa do mal ao outro ${ }^{7}$ (Metafísica, A 6, 988a 9-15).
\end{abstract}

Aristóteles identificava o Uno à "Forma” e a Díade à "matéria". As Ideias seriam geradas pelo Uno como "causa formal" e pela Díade como "causa material", que, mediatamente, são as causas dos Entes Matemáticos "intermediários" e do sensível. As Ideias são a causa formal imediata do sensível ao delimitarem - em um plano qualitativamente diferente da delimitação do Uno sobre a Díade -, a Díade de grande-e-pequeno, que é o princípio material. A hierarquia do real atribuída a Platão por Aristóteles é: primeiro, os Princípios do Uno e da Díade; abaixo, os Números Ideais e as Ideias; em seguida, entre as realidades sensíveis e as Idéias existem os Entes Matemáticos “intermediários”.

No entender de Reale (2004, p. 30), o que chama atenção no texto de Aristóteles é que seu fundamento não se encontra nas passagens dos diálogos, mas fora deles. Aristóteles, na Física, sugere que os pensamentos sobre os quais apoia sua reconstrução histórica e crítica do platonismo são os "ensinamentos não-escritos" de Platão: "Car le réceptacle et l'étendue sont une suele et même chose; certes sa terminologie n'est pas la même pour le participant dans cet

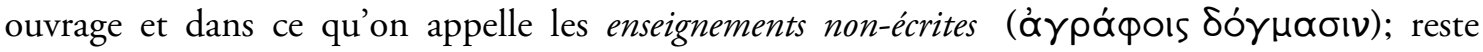
qu'il a identifié le lieu et l'étendue (Il faut citer Platon car, si pour tous le lieu est quelque chose, lui seul a essayé de dire ce qu'il est)" (209b10-15).

Espeusipo traz, ao primeiro plano, os entes Matemáticos e considera-os a estrutura unificadora do sensível. Ele não admite as Ideias, eixos de sustentação dos diálogos, e os Números

\footnotetext{
7 Outra passagem sobre a os primeiros princípios é: "Portanto, posto que as Formas são causas das outras coisas, Platão considerou os elementos constitutivos das Formas como o elemento de todos os seres. Como elemento
} 
Ideais como substâncias verdadeiras. Reinterpreta os princípios do Uno e da Díade, considerando-os em dimensão matemática do Uno e dos Muitos; mas o Uno não é identificado com o bem e os Muitos com o mal, porque estes se manifestam no principiado. Sua hierarquia do real é, também, diversa. Os números matemáticos, a psykhé e os sensíveis não derivam imediatamente do Uno e do Múltiplo, mas de princípios correspondentes a eles (Cf. Reale, 2004, p. 30; Espeusipo frs. 48-88. In: Isnardi Parente, 1980).

Xenócrates procura uma interpretação de maior fidelidade aos ensinamentos de Platão. Ele admite a teoria da Ideias e dos Números Ideais como o eixo de sustentaçáo do pensamento platônico, embora derivados dos princípios do Uno e da Díade. Distingue-se de seu mestre, em algumas considerações sobre a Díade e sua acentuada conexão entre os Entes Matemáticos e os Números Ideais (Cf. Reale, 2004, p. 31. Xenócrates frs. 92-122. In: Isnardi Parente, 1982).

O paradigma hermenêutico da primeira academia fundamenta-se na teoria dos Princípios e a considera a base sob a qual é deduzida a "teoria das Ideias". Esse paradigma antecipa algumas das teses da Escola de Tübingen, mas negligencia a "dimensão histórica" do platonismo e a ótica dela derivada. A interpretação da primeira Academia interessava-se exclusivamente do ponto de vista teórico pelas doutrinas de Platão, valorizando o ensinamento oral, mas subvalorizava os escritos.

Esse paradigma, em certo sentido, dá nítida prioridade às "Doutrinas não-escritas", com uma fortíssima carga teorética, como veremos. A esse paradigma se remete hoje a Escola de Tübingen em larga medida, porque ele volta a oferecer a perspectiva que era canônica no século IV a.C. e, portanto, constitui o paradigma consagrado, com a máxima autoridade, pelo próprio Platão, pelos seus discípulos diretos e pelos contemporâneos iniciados às doutrinas da Academia. Todavia, permanece uma diferença notável, devida à "historicidade" e à "cientificidade" que dão ao novo paradigma uma estatura diferente (justamente em dimensão histórica e científica), totalmente ausente no antigo paradigma (Reale, 2004, p. 25: grifos do autor).

O segundo paradigma foi esboçado parcialmente no médio-platonismo, século II d.C., e formulado em suas mais altas categorias metafísicas pelos neoplatônicos, nos séculos III e IV d.C.

O paradigma médio-platônico encontra-se desenvolvido no Didascálio de Albino. Existe um interesse teorético predominante. Privilegia-se a estrutura hierárquica da realidade

material das Formas ele punha o grande e pequeno, e como causa formal o Um: de fato, considera que as Formas < e > os números derivassem por participação do grande e do pequeno no Um” (Metafísica, A6, 987a15-20). 
diferenciando-a em três níveis: "Primeiro Intelecto", que desperta a "Alma do Mundo" e a volta para si, gerando o "Intelecto da Alma do Mundo". Segundo Reale (2004, p. 34), existe a tendência em sintetizar a concepçáo do mundo das Ideias com o Intelecto divino de Aristóteles e a concepção platônica das Ideias transcendente é defendida conjuntamente com as formas imanentes aristotélicas.

Albino identifica o "Primeiro Intelecto" com a realidade primeira, o que explica a razão pela qual o Uno e a Díade foram deixados à margem. Os médio-platônicos, portanto, não falam dos Princípios da realidade, mas dos princípios - Deus, Idéias e Matéria -, que explicam o cosmo. Considera-se o fim do homem a sua assimilação a Deus.

A interpretação dos médio-platônicos comete uma série de anacronismos ao ler nos diálogos doutrinas posteriores, principalmente, de Aristóteles e dos estóicos (Cf. Reale, 2004, p. 34). Sintetizam o mundo das Ideias com o pensamento aristotélico do Intelecto divino que pensa-a-si-mesmo. E as Ideias transcendentes eram consideradas os "Inteligíveis primeiros", ou seja, a causa, e as formas aristotélicas eram compreendidas como efeitos dos primeiros, isto é, "Inteligíveis segundos".

O paradigma esboçado antes foi ampliado significativamente no âmbito teorético com Plotino e atingiu sua máxima expressão em Proclo. Os neoplatônicos estavam convencidos de encontrarem nos escritos platônicos, sobretudo no Timeu, considerado o escrito por excelência, e no Parmênides, no qual encontravam a estrutura da realidade, suas próprias doutrinas. Plotino desenvolveu a estrutura da realidade fundada sobre as hipóstases do Uno, do Nôus e da Alma, que procedem hierarquicamente uma da outra ${ }^{8}$.

E nas Enéadas V, 1, 8, Plotino afirma que essa doutrina encontra-se no próprio Platão. A doutrina plotiniana do Uno como o princípio supremo acima-do-ser-e-do-pensamento e

\footnotetext{
8 "Podemos dizer que este é o primeiro ato da geração: nada possuindo e nada buscando em sua perfeição, o Uno transbordou e sua superabundância, produziu algo diverso dele mesmo. O que foi produzido voltou-se de novo para a sua origem e, contemplando-a e sendo por ela preenchido, tornou-se a Inteligência. $\mathrm{O}$ ato de ter-se detido e se voltado para o Uno deu origem ao Ser; o ato de ter contemplado o Uno deu origem à Inteligência. $\mathrm{O}$ ato de ter-se detido e se voltado para o Uno, a fim de contemplá-lo simultaneamente Ser e Inteligência. Desse modo, tornando-se semelhante ao Uno por contemplá-lo, repetiu o ato do Uno e emitiu um grande poder. Esse segundo transbordamento, o da essência da inteligência, é a Alma, que veio assim à existência, mas a inteligência permaneceu inalterada. A Alma surgiu como uma idéia e um ato da Inteligência imóvel - que também proveio de uma origem [o Uno] que permaneceu imóvel e inalterada -, mas a operação da Alma náo é imóvel, pois ela gera a sua própria imagem [ou hipóstase] pelo movimento: a contemplação do que lhe deu origem a preenche e, empreendendo um movimento no sentido contrário [descendente], ela gera a sua imagem [ou hipóstase]. Essa imagem da Alma sáo os sentidos e o princípio vegetativo.” Plotino, Enéadas, v. 2.
} 
coincidente com o Bem é um repensamento dos "ensinamentos não-escritos" de Platão. Para Reale (2004, p. 35), “poder-se-ia até mesmo afirmar que sem as 'Doutrinas não-escritas' o neoplatonismo não teria se desenvolvido”.

Os neoplatônicos revivem os "ensinamentos não-escritos", em particular a doutrina do Uno como princípio supremo semelhante ao Bem, entendido como "acima-do-ser-e-dopensamento" e a consequente henologia. Retomam a "Díade indefinida” considerando-a como procedente do Uno. A teoria dos Números Ideais é retomada e amplamente desenvolvida, mas é colocada em estreita relaçáo com os diálogos. Esse paradigma valoriza principalmente os diálogos, interpretando-os em chave exclusivamente teorética. Os "ensinamentos não-escritos" são considerados em seus pontos e consequências especulativas?

O paradigma neoplatônico predominou durante a Idade Média, mas passou por simplificaçóes teoréticas profundas em muitas de suas teses centrais e foi largamente reduzido ao médio-platônico. Nesse período, o conhecimento dos diálogos era limitadíssimo, pois não foram traduzidos para o latim.

No Renascimento, século XV d.C., promoveu-se uma renovaçáo dos estudos platônicos provocados pela tradução de todos os diálogos e de suas leituras dentro da ótica neoplatônica com todas as implicaçôes teoréticas decorrentes. Esse paradigma prevaleceu até metade do século XVIII quando sucumbiu a pesadas críticas.

O terceiro paradigma na história das interpretaçóes de Platão e sobre o qual a crítica contemporânea passa a dedicar a sua atenção foi formulado de maneira eficaz por Schleiermacher no princípio do século XIX.

$\mathrm{Na}$ ótica de Schleiermacher, os diálogos são obras de arte em que ocorre a conjunção perfeita da forma com o conteúdo e se tornam a "comunicação filosófica” por excelência. A forma dialógica assume, afirma Vaz (1990), "uma dignidade ontológica que a torna, por excelência, imagem e expressão do Absoluto”. A compreensão de todos os diálogos, consequentemente, implica a compreensáo de todo o pensamento de Platáo: o seu método e o seu

\footnotetext{
9 Segundo Reale (2004, p. 25. Grifo do autor), "esse paradigma centra-se, a seu modo, como veremos, sobre os escritos platônicos, com interesses exclusivamente teoréticos [...] As "Doutrinas náo-escritas" foram levadas em consideração [...] mas apenas em alguns de seus pontos e em algumas de suas conseqüências de caráter teorético, e nas explicaçóes de algumas de suas importantes implicaçóes especulativas".
} 
conteúdo. Segundo Reale (2004, p. 41-42), a identificação entre forma e conteúdo são pressupostos metafísicos da filosofia idealista da identidade e fundam esse paradigma.

Os diálogos, dentro da ótica dos românticos, exprimem um "sistema preciso" elaborado a partir de um nível básico e construído até alcançar um nível "construtivo e sistemático". Dessa forma, ao reconstruir o plano de cada diálogo e o plano geral dos vários diálogos em suas relaçóes intrínsecas e extrínsecas, reconstruir-se-ia o próprio "sistema” de Platão.

Nesse paradigma, os diálogos possuem um valor autárquico absoluto: o pensamento de Platão encontra-se exclusivamente em seus escritos. Por consequência, os "ensinamentos nãoescritos" transmitidos pelos primeiros acadêmicos e pela longa tradição indireta subsequente e a secular interpretação neoplatônica são destituídas completamente de valor. Segundo Schleiermacher (2002, p. 45), "e mesmo onde, aqui e ali, são citados [por Aristóteles] outros ensinamentos que se perderam ou orais, essas citaçóes não contêm nada que não se leia nos nossos escritos [os diálogos] ou que se afaste inteiramente deles".

As teses expostas são as bases do paradigma schleiermachiriano, mas se distinguem do modo como Scheleiermacher reconstruiu o pensamento platônico. O paradigma abriu uma fase de pesquisa especializada em que foram postos em ação refinados métodos filológicos e hermenêuticos. Os novos métodos, contudo, não resolveram os intricados problemas de interpretação surgidos no interior da estrutura do paradigma. Os problemas podem ser enquadrados em três diferentes grupos:

a) São os problemas essências: revelam o objeto da pesquisa. Correspondem à análise dos diálogos considerados como a expressão máxima da filosofia de Platão. Aprofundam-se as pesquisas sobre a autenticidade dos diálogos, sua sucessão cronológica, sua forma e conteúdo; procura-se eliminar a dimensão da tradiçáo indireta, pois ela contradiz o paradigma.

b) A segunda classe de problemas são as tentativas de reconstrução, influenciadas e determinadas pelos vários sistemas teórico-filosóficos dos próprios estudiosos, da suposta "unidade" dos diálogos. Acontece a introdução de critérios teóricos de diversos autores; introduzem-se elementos políticos, biográficos e psicanalíticos na busca de explicação para os diálogos; explicita-se a evolução dos diálogos e do pensamento platônico.

c) O terceiro grupo de problemas surgiu da necessidade de considerar os "ensinamentos não-escritos" dentro do paradigma. Tentou-se coincidir os "ensinamentos não-escritos" com a 
senilidade de Platáo. Revalorização dos ensinamentos orais, tentativa de relacioná-los com os diálogos dialéticos. E os primeiros esboços de um novo paradigma, com a consequente perda de nitidez do paradigma schleiermacheriano.

No século XIX, alguns estudiosos ${ }^{10}$ já alertavam para a necessidade de levar a tradição indireta em séria consideração para se obter uma interpretação segura de Platão. As posiçóes desses intérpretes elevaram ao primeiro plano fatos significativos que não eram explicados pelo paradigma schleiermacheriano (Reale, 2004, p. 45), consequentemente, surgiu a necessidade da articulação do paradigma para solucionar seus problemas internos. Eduard Zeller (1963) promoveu a primeira articulação e obteve enorme sucesso. Os “ensinamentos não-escritos", para esse autor, não interferem na interpretação dos diálogos, porque Platáo os formulou na velhice, provavelmente, na época de composição das Leis. Eles apresentam, além do mais, contradições internas, acréscimos e adaptaçóes promovidas pelos seus transmissores. A articulação promovida por Zeller desloca o problema, removendo seus aspectos capazes de pôr em crise o paradigma.

A crítica de Zeller e de seus seguidores ao valor dos testemunhos aristotélicos, classificando-os como equivocados e adaptações, compromete, contudo, toda a história da filosofia fundada na doxografia. Deve-se ou aceitar a pesquisa doxográfica em relação a Platão, ou se deve negar sua validade científica para todos os filósofos antigos. A tradição sobre Platão apresenta uma grande confiabilidade, visto que os testemunhos, em sua maioria, encontram-se conservados pelos seus discípulos diretos, participantes ativos das discussóes doutrinais na Academia.

Contribuição notável para o paradigma schleiermacheriano, no século XX, foi promovida pelo helenista alemão Wilamowitz-Moellendorff (1919) que reivindicou a autenticidade da Carta VII e abriu a via de interpretação de Platão em chave política. Os maiores frutos dessa via estão na obra Paidéia, de Werner Jaeger (2003). Mas a necessidade de articulação do paradigma intensifica-se com as contribuiçôes de Leon Robin, Julius Stenzel e P. Wilpert, que trouxeram ao primeiro plano os "ensinamentos náo-escritos".

\footnotetext{
${ }^{10}$ Os principais são Boeckh, Brandis, Trendelenburg e Weisse.
} 
Conquanto o paradigma romântico fosse rearticulado buscando uma interpretaçáo que conjugasse os "ensinamentos não-escritos", paralelamente, esboçava-se um paradigma alternativo, que revigorava a tradição indireta e passou a ler os diálogos à sua luz.

O sistema filosófico de Platão não é expressamente desenvolvido nos diálogos, mas só se encontra, pelo menos a partir da República, subjacente a eles. Esse sistema é um sistema de dedução, e precisamente um sistema dualístico, pois ele conduz "todas as coisas” a dois fatores originários essencialmente diferentes entre si (Gomperz, 1953 apud Reale, 2004, p. 48).

Os primeiros esboços são ainda tentativas incertas e cambaleantes, que, no entanto, abriram o caminho pelo qual a Escola de Tübingen desenvolveu o novo paradigma.

\section{O Paradigma da Escola de Tübingen: sistematizaçáo da filosofia de Platáo fundada nas "doutrinas não-escritas"}

O paradigma schleiermacheriano dominou os estudos platônicos por mais de um século. Mas ele não explicava de modo eficiente as relaçóes entre os diálogos e a doutrina de Platão comunicada exclusivamente pela "oralidade dialética" e transmitida pela tradição indireta: os "ensinamentos não-escritos". Mediante os problemas deixados sem solução, que minavam as bases do paradigma, a Escola de Tübingen propôs um novo paradigma alternativo na tentativa de alcançar a exata dimensão da "oralidade” e da "escrita” em Platão. Reale expressa exemplarmente a problemática dentro da qual trabalha o novo paradigma:

\footnotetext{
O problema geral da interpretação platônica, tal como hoje se apresenta, consiste em reconstruir de maneira adequada as relaçóes entre as doutrinas que lemos nos escritos de Platão e as "Doutrinas não-escritas", que Platão quis comunicar exclusivamente mediante a dimensão da oralidade dialética, mas conhecidas indiretamente por meio dos seus discípulos. [O paradigma da Escola de Tübingen explica] as exatas concepções platônicas a respeito do "escrito" e da "oralidade", e a respeito das suas significativas diferenças e do seu diferente alcance de conteúdos doutrinais e de eficácia comunicativa, bem como sobre o modo de operar a sua mediação (Reale, 2004, p. 24, grifos do autor).
}

O paradigma tübingense critica amplamente e de maneira irreversível as estruturas de fundação do paradigma tradicional, ou seja, a autarquia total ou de grande parte dos diálogos. 
Estrutura-se uma nova relação que parte da oralidade e a transforma em eixo de sustentação sobre o qual os diálogos são lidos; portanto, "inverte" as relaçóes entre o paradigma anterior e os diálogos. Abre novas e promissoras perspectivas para a leitura dos diálogos e na interpretação do conjunto do pensamento platônico.

O paradigma tübingense permite a reconstrução do platonismo, deduzindo-o de dois princípios supremos: o Uno e a Díade, o que soluciona o desafio de Leibniz: "se alguém reduzisse Platão a um sistema, prestaria um grande serviço ao gênero humano”. A principal contribuição trazida pelo paradigma da Escola de Tübingen, segundo seus defensores, é a possibilidade de reconstruir a unidade do pensamento de Platão, sistematizá-lo, fundando-o sobre dois princípios, sem, para tanto, referirem-se a perspectivas teóricas estranhas aos próprios diálogos ou à tradição indireta, sem nenhum tipo de ideologia política, psicanalítica ou filosófica, "mas a uma interpretação que remonta à viva voz de Platáo", ou seja, a dimensão da "oralidade dialética" à qual ele confiou os pontos-chave de sua doutrina como socorro aos diálogos ${ }^{11}$.

Eis em que sentido a releitura de Platão realizada pela Escola platônica de Tübingen deve ser considerada, nos seus fundamentos, como proposta de um paradigma alternativo ao moderno: os diálogos platônicos não são autárquicos: sozinhos não se explicam adequadamente, porque deixam abertos numerosos problemas centrais. Tais problemas são resolvidos à luz das "Doutrinas não-escritas", de onde emerge que o vértice da metafísica platônica não é a teoria das Ideias, mas a doutrina dos Princípios (Reale, 2004, p. 534: grifos do autor).

Fundados sobre as bases hermenêuticas do novo paradigma, os estudiosos da Escola de Tübingen e seus colaboradores leem os diálogos sob nova ótica e o problema do significado do escrito platônico é redimensionado em soluçóes mais precisas.

O paradigma da Escola de Tübingen desloca a época de composiçâo dos ensinamentos orais da velhice, como propunha os defensores do paradigma schleiermachiriano, para, certamente, a época dos diálogos centrais. Os ensinamentos orais passaram a ser considerados o pano de fundo de muitos diálogos, principalmente aqueles mais importantes para reconstruir o platonismo, como o Fédon e a República. As partes centrais desses escritos, que não receberam

\footnotetext{
11 "Com efeito, o maior esclarecimento trazido pelo novo paradigma refere-se à própria possibilidade de reconstruir um 'sistema', ou seja, ver a unidade do pensamento de Platão, náo mais se referindo às perspectivas teóricas estranhas ao platonismo, e menos ainda a ideologias políticas ou à psicanálise, mas a uma interpretação que remonta à viva voz de Platão, ou seja, à dimensão da oralidade dialética à qual ele confiou a sua mensagem” (Reale, 2004, p. 53).
} 
explicações precisas no passado, clarificam-se com a chave interpretativa fornecida pela tradição indireta.

Os diálogos, ao contrário da alegação de alguns estudiosos contrários ao novo paradigma, não tiveram seu valor diminuído, mas existe uma "prioridade filosófica" da tradição indireta, porque é por meio dela que é revelado o pensamento de Platáo sobre os Princípios Primeiros, isto é, "as coisas de maior valor".

A ironia, componente essencial da expressão de Platão, também é reinterpretada. Em Platáo, a ironia possui um valor metodológico delimitado ao levar o leitor, por meio de jogos, fingimentos e invençóes, a buscar a verdade mostrando o absurdo das posiçóes opostas. Os muitos enigmas presentes nos escritos e o que Platáo realmente disse a sério são esclarecidos. Os ensinamentos orais oferecem a chave histórica para fazer a "máscara cair" e revelar a "seriedade filosófica" e os "fundamentos construtivos" da ironia (Reale, 2004, p. 90). Esse autor expressa a dimensão em que os diálogos são considerados no novo paradigma:

\footnotetext{
No âmbito do novo "paradigma", a perda de autarquia dos diálogos, devida à valorização da tradição indireta, não significa perda de valor, mas, ao contrário, um incremento do seu valor, porque se mostram iluminados nas suas zonas de sombras, mostram-se mais claros, mais ricos de instâncias e de tensóes, abertos a um horizonte mais amplo. Ademais, o plus revelado pela tradição indireta se reduz a um discurso muito breve. $\mathrm{O}$ discurso sobre os "fundamentos últimos" é, com efeito, um discurso sempre muito breve: é como um trecho de uma escalada, que é o mais breve e, ao mesmo tempo, o mais comprometedor. Os escritos platônicos permitem subir toda a montanha, mas não permitem conquistar o cimo; a tradição indireta, ao invés, nos póe justamente em condiçôes de alcançá-lo (p. 88).
}

Dentro dos limites do antigo paradigma, estudiosos sugeriram a concepçáo evolutiva do pensamento de Platáo e a tentativa de sua reconstrução genética foi buscada por intermédio da análise estilística, da estatística linguística e dos métodos da filologia moderna. Os pressupostos sobre os quais o método genético apoia-se foram postos em grave crise pelo novo paradigma. Os defensores desse método aplicam o princípio segundo o qual o pensamento de Platão está "unicamente" expresso nos diálogos. Mas esse pressuposto, não demonstrado, somente é válido no caso de todo o escrito expressar todo o seu pensamento, mas Platão tematiza e constrói os diálogos em relação precisa com uma temática proposta; além do mais, os diálogos são adaptados aos limites de seus personagens e a contextos específicos. Muitas passagens remetem para além do escrito. Segundo Szlezák (2005, p. 29-39), existem passagens em toda a obra escrita de Platão 
cujo locutor deixa entender que ele teria mais coisas fundamentais a dizer, mas que não o faria naquele lugar e momento. Essas "passagens de retenção" remetem ao ensino oral de Platão ${ }^{12}$. Existe uma distinção dos níveis de reflexão filosófica entre os diálogos: alguns se propóem a fins limitados em relação aos outros. $\mathrm{O}$ método genético, consequentemente, somente alcança resultados confiáveis sobre o estilo e o desenvolvimento de Platão como escritor, mas é ineficaz quanto à sua reflexão filosófica: o desenvolvimento do pensamento de Platáo não coincide com o desenvolvimento do seu estilo.

Segundo o próprio Platáo, existe uma mobilidade entre os limites da oralidade e do escrito, pois, no Fedro, ele afirma que a discussão oral precede o escrito. Os diálogos, em diversos pontos, remetem-se aos "ensinamentos não-escritos".

Giovanni Reale (2004, p. 93: grifos do autor) conclui: a) o pensamento de Platáo vai além do que ele fixava por escrito; b) a interpretação da tradição indireta permite ter acesso a esse pensamento; c) é estabelecido que os "ensinamentos não-escritos" são muito anteriores ao que se propunham os defensores do antigo paradigma, a questão da evoluçáo do pensamento de Platáo deve ser abordada "com base nas relaçóes entre obra escrita e ensinamento oral, isto é, com base nas relaçôes entre duas tradiçôes que nos chegaram”.

\section{Fundamentaçáo do Novo Paradigma: "autotestemunhos" do Fedro e da Carta VII}

O paradigma proposto pela Escola de Tübingen, segundo seus defensores, fundamenta-se nos próprios escritos de Platáo. Os “autotestemunhos" negam expressamente e por escrito a autarquia dos diálogos na comunicação das coisas de maior valor, i.é., os princípios primeiros do Uno e da Díade. Para comunicá-los, é necessário recorrer à “oralidade dialética”.

Os estudiosos, no decorrer do século XIX, identificaram os "autotestemunhos" como o principal "fato contrário" ao paradigma de Schleiermacher, comprometendo-o em suas estruturas. Para eliminá-lo, os estudiosos interpretaram artificialmente e com habilidade os "autotestemunhos", mas sempre dentro dos esquemas do antigo paradigma. A interpretação do

12 "Passagens de retenção" é uma expressão cunhada por Szlezak e encontra-se nas obras Struttura e finalità dei dialoghi platonici. Che cosa significa "venire in soccorso al discorso?". In: "Revista di Filosofia neoscolastica", 81, 1989, p. 523-542. E em Ler Platão. Loyola, 2005. Cf. também Perine, 2004, p. 15-16. 
Fedro e da Carta VII é essencial e irrenunciável para compreender Platão na dimensão do paradigma da Escola de Tübingen. O discurso do Platão no Fedro é uma crítica à funcionalidade do escrito como transmissor da verdade.

Para Platão, o escrito não aumenta a sabedoria e não ajuda a reminiscência, mas aumenta a aparência da sabedoria e ajuda a recordação das coisas que já se conhecem e foram impressas na alma (Fedro, 274c-276b) por meio dos sentidos. Ele não é capaz de defender-se contra as críticas que lhe são imputadas, mas necessita do socorro de seu autor para tanto (Fedro, 275d-e). Os discursos orais são impressos na alma, enquanto os discursos escritos são imagens dos discursos feitos na dimensão da oralidade (Fedro, 276a). O escrito é um “jogo" com o propósito de trazer à memória uma simples lembrança que é conhecida pela alma pelo intermédio do corpo, mas que foi esquecida por motivos contingentes, como a velhice. Portanto, muito mais eficaz do que o escrito é o discurso oral, porque ele traz à luz o conhecimento impresso na alma de quem o comunica.

Sócrates - O que é escrito com o conhecimento na alma de quem estuda, e que não somente é capaz de defender-se, que de falar e silenciar quando preciso.

Fedro - Referis-te ao discurso de quem sabe, discurso vivo e animado, do qual, com toda a justiça, pode ser considerado simples simulacro o discurso escrito (Fedro, 276a).

O escritor, para produzir discursos belos, deve conhecer a verdade e o método dialético para subdividi-la em suas respectivas partes, deve conhecer também a alma daqueles para quem escreve e a maneira adequada de escrever que condiga com as possibilidades dessas almas e, consequentemente, deve estruturar o escrito para alcançar uma adequada correspondência entre seu conteúdo e a predisposiçáo da alma do leitor. Ainda assim, o escrito náo poderá transmitir o conhecimento verdadeiro concernente ao bem e ao mal, pois esses conhecimentos são legados à oralidade que escreve na alma as coisas justas, belas e boas (Fedro, 277b-c).

A posição platônica sobre as relaçóes entre escrita e oralidade é relatada no mito do rei Tamuz. O mito é utilizado, porque permite uma aproximação com a verdade ${ }^{13}$. Platáo começa com um jogo sobre o tema de sua narração: Sócrates afirma que ouviu dos antigos o mito sobre a escrita. O jogo e o mitologizar (Fedro 276b1; 276c3; 276e1-3; 277a5; 278a3) são dimensóes do 
escrito. Platão os usa como imagens para transmitir nos diálogos os pontos-chave de seu pensamento. Os mitos são aproximações capazes de transmitir aos homens as imagens do real.

O demônio Teute inventou diversas artes: os números, a geometria, a astronomia, os jogos de tabuleiro e de dados e a escrita. Teute apresentou as várias artes ao rei do Egito, Tamuz, que as elogiava ou criticava. Teute apresenta a escrita como o remédio para o esquecimento e para a ignorância. Mas Tamuz, contra toda a perspectiva dos leitores modernos, responde-lhe que a escrita não é um bem para a memória, mas, ao contrário, as pessoas deixariam de exercitar sua memória, pois os escritos tomarão seu lugar.

Dada a afeição que lhe dedicas, atribui-lhe ação exatamente oposta à que lhe é própria, pois é bastante idônea para levar o esquecimento à alma de quem aprende, pelo fato de não obrigá-lo ao exercício da memória. Confiante na escrita, será por meios externos, com a ajuda de caracteres estranhos, não no seu próprio íntimo e graças a ele mesmo, que passarâo a despertar suas reminiscências. Não descobriste o remédio para a memória, mas apenas para a lembrança. O que ofereces aos que estudam é uma simples aparência de saber, não a própria realidade. Depois de ouvirem um mundo de coisas, sem nada terem aprendido, considerar-se-ão ultra-sábios, quando, na grande maioria, não passam de ignorantóes, pseudo-sábios, simplesmente, náo sábios da verdade (Fedro, 274c-275b).

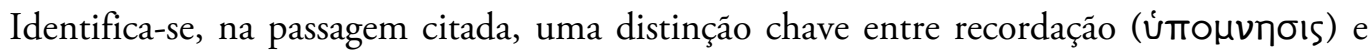
reminiscência $(\mu \nu \eta ́ \mu \eta)$. A escrita traz à luz o conhecimento obtido por meio das sensaçóes, mas que por algum motivo foi esquecido. Mas ela náo é capaz de transmitir, de tornar patente o verdadeiro conhecimento reminiscente. O conhecimento verdadeiro é alcançado por meio de um movimento interior da alma que traz à luz as Ideias ( $\varepsilon i \delta \circ \varsigma$ ), que foram uma vez contempladas ${ }^{14}$.

O mito da invenção da escrita coaduna-se com a visão platônica, presente em vários diálogos, sobre o pensamento e o conhecimento. Para Platão, existe um discurso interno, próprio da alma, anterior à fala e à escrita, superior e melhor do que este. O discurso da alma educa o homem. Segundo Cardoso (2006), a noção de consciência surge embrionária nesta Paideia:

\footnotetext{
${ }^{13}$ Segundo Cardoso (2006, p. 92), "o mito é uma linguagem imperfeita, mas também funcional, pois quando se trata dos seres humanos nunca se pode apreender a verdade na sua limpidez, porém a narração mitológica nos faz pelo menos penetrar no umbral da verdade que se busca”.

${ }^{14}$ A distinção entre memória, recordação e conhecimento impresso na alma é atestada no Filebo: "Sócrates -Quando aquilo que a alma sentiu antigamente com o corpo e sente agora só em si mesma, sem o corpo, tanto quanto possível, eis aquilo a que chamamos recorda-se, não é verdadeiro? Protarco -Perfeitamente. Sócrates -E quando, tendo perdido a recordação quer duma sensação quer dum conhecimento, a alma recorda de novo, só em si mesma, chamamos a tudo isto reminiscência e recordações. Protarco - Muito bem.” (Platão, 1999, p. 200)
} 
"aparece aqui de modo embrionário aquilo que a filosofia ocidental chamará de consciência, que se forma náo pela fixaçáo da escrita, mas pela concreta e histórica experiência da vida de cada um" (p. 75).

A escrita, por outro lado, não é totalmente desvirtuada e tão pouco se considera a oralidade como o meio absoluto por meio do qual a verdade alcança os homens, como sustentam os tübingenses. A escrita condenada é a que se distancia voluntariamente da verdade e, nesse sentido, a oralidade de discursos vazios é também condenada. Sócrates (Fedro, 235b) afirma que homens sábios já falaram e escreveram sobre assuntos do mais alto valor. A relação entre discurso oral e escrito é a "referência à verdade e não simplesmente [a] superioridade dialética" (Cardoso, 2006, p. 76). O conhecimento situa-se na alma e é transmitido pelo diálogo com o outro: quer seja oral ou escrito, apesar da preponderância dos discursos orais.

A crítica platônica situa-se no contexto cultural da Grécia do século V. Nesse período, a vida social na pólis era governada pelo discurso, pois todas as decisóes políticas eram debatidas na ágora. Algumas pessoas especializaram-se em escrever e ensinar as técnicas de confecção do discurso. Platão posiciona-se diametralmente contra esses sofistas ou retores. No Fedro, a personagem Lísias é apresentada como o estereótipo dessa classe. Eles usavam seus discursos como o meio para convencerem as pessoas a adotarem suas posiçóes, mas seus discursos apresentavam coisas falsas ou parcialmente verdadeiras como a verdade única. Essa atitude implicava erros epistemológicos, éticos e estéticos e prejudicava a cidade. Os discursos sofísticos não dominavam a técnica correta, pois não conheciam a alma de seus interlocutores. A filosofia, no entanto, possuía as condiçôes necessárias para vincular a verdade ao discurso.

O escrito platônico situa-se historicamente em um contexto político, mas não se reduz a ele, porque implica uma dimensão epistemológica explorada pela Escola de Tübingen. Platão retoma na Carta VII os problemas sobre a relação entre escritura, oralidade e verdade trabalhadas anteriormente no Fedro. Esses problemas são esclarecidos e desenvolvidos para explicar a relação entre Platão e Dionísio de Siracusa. O discurso da Carta VII situa-se na órbita de discussóes políticas, mas, a exemplo do Fedro, não se limita a elas, pois possui um fundamento epistemológico.

Platão, buscando confirmar a verdade das afirmaçóes de alguns que diziam que Dionísio era filósofo, submete-o a uma "prova": expõe as dificuldades dos "estudos filosóficos", sua 
natureza, sua extensão e os esforços exigidos (Carta VII, 340b-c). As atitudes dos ouvintes frente a essas complicaçóes eram: se fossem filósofos, ficariam maravilhados e trilhariam imediatamente o caminho da filosofia; mas, se náo possuíssem uma natureza de filósofos, contentar-se-iam com as simples opinióes e alguns convencidos que conhecem suficientemente bem a matéria acreditaram não precisarem se esforçar mais para conhecê-la (Carta VII, 340c-341a).

A reação de Dionísio à "prova” foi péssima. Depois de ouvir uma única lição oral de Platão, ele julgou saber muitas coisas, principalmente "as mais importantes”, por tê-las ouvido de outros e pensou ser capaz de escrevê-las, assim como outros já haviam tentado fazer. Platão, no entanto, rejeita sumariamente a capacidade desses homens de escreverem sobre o que ouviram dele, pois náo é possível exprimir, em textos, adequadamente as coisas de maior valor e, se fosse possível, ele mesmo o teria feito.

$\mathrm{O}$ que estou em condiçóes de afirmar de quantos escreveram e ainda virão a escrever com a pretensão de conhecer as questóes com que me ocupo, quer as tenham ouvido de mim mesmo ou de outras pessoas, quer as descobrissem por esforço próprio, é que, no meu modo de pensar, eles não entendem nada de nada de todas essas questóes. De mim, pelo menos, nunca houve nem haverá nenhum escrito sobre semelhante matéria. Não é possível encontrar a expressão adequada para problemas dessa natureza, como acontece com outros conhecimentos. Como consequência de um comércio prolongado e de uma existência dedicada à meditaçáo de tais problemas é que a verdade brota na alma como a luz nascida de uma faísca instantânea, para depois crescer sozinha (Carta VII, 341 b-d, grifo nosso).

Para conhecer as coisas de maior valor, deve-se fazer uma longa série de discussóes orais entre quem ensina e quem aprende, deve-se ter uma vida apropriada para que brote na alma o conhecimento dos princípios. Se fosse oportuno e necessário colocar essas coisas por escrito, Platáo sublinha que ele poderia fazê-lo do melhor modo possível, mas poucos homens se beneficiariam com a sua leitura e estes seriam justamente aqueles capazes de encontrar a verdade com poucas sugestóes. A turba, ao contrário, não o compreenderia, além de ignorá-lo e desprezálo.

Segundo Platão, usa-se nos discursos (a) o nome, (b) a definição, (c) a imagem (d) para alcançar o conhecimento (e) que leva a captar o inteligível. Os três primeiros são obscuros e distanciam-se do inteligível. Podem, no entanto, levar a captar o inteligível caso sejam adequadamente discutidos, mas podem, por outro lado, tornarem-se um obstáculo para alcançar o verdadeiro conhecimento, justamente por sua natureza (Carta VII, 342a-344d). A maioria dos 
homens, por possuir uma natureza ruim, perde-se nas quatro primeiras etapas e não consegue alcançar o conhecimento de natureza superior. Assim, os autores sérios não colocariam as coisas sérias em escritos: estariam impressas em suas almas e nunca seriam esquecidas e também para não expô-las “à inveja e à incompreensão do público".

Platão, em seguida, afirma que aqueles que escreviam sobre essas coisas não o faziam pelos motivos certos: os escritos não são úteis, porque não fornecem subsídios hipomnemáticos: quem compreendeu as coisas de maior valor e as imprimiu na alma não pode esquecê-las, pois se constituem de breves proposiçóes. Mas as escreveram por ambição e sem a adequada preparação. Dionísio, por exemplo, o fez depois de ouvir apenas uma única lição (Carta VII, 344d-345c).

\section{Consideraçóes Finais}

A Escola de Tübingen, com a posterior contribuição dos pesquisadores da Università Cattolica di Milano, desenvolveu um novo paradigma histórico-hermenêutico com recursos para interpretar vigorosamente o pensamento platônico presente nos diálogos à luz dos "ensinamentos não-escritos". As vias interpretativas, a sua "coerência" e "consistência” permitem novas soluçóes aos problemas deixados em aberto no seio do paradigma anterior.

O novo paradigma, na ótica de seus defensores, aproxima-se contundentemente da verdade da mensagem de Platáo, isto é, possui maior adaquato ad rem, possibilita novas alternativas para solucionar as aporias dos diálogos, o que leva a compreender Platáo em nova dimensão. Amplia, portanto, o alcance dos paradigmas anteriores pela "revolução" do método hermenêutico.

O paradigma da Escola de Tübingen, evidentemente, desencadeia conclusóes que excluem uma série de desenvolvimentos alcançados no interior do paradigma schleiermacheriano (Guthrie, 1988, p. 440). No novo paradigma, por consequência, "não se poderá mais falar de um Platão não-metafísico, ou não-sistemático, influenciado pelo ceticismo, ou não-unitário e de vários modos fragmentário, autocrítico e aporético" (Reale, 2004, p. 535: grifos do autor). Os problemas de interpretação dos diálogos não serão resolvidos recorrendo-se a "empréstimos de filosofias modernas e contemporâneas" ou a componentes políticos, biográficos e psicanalíticos extrínsecos à filosofia platônica, mas dever-se-á recorrer às soluçóes do próprio Platáo propostas no nível da 
oralidade dialética e transmitidas pela tradição indireta, e que possuem alusóes e remissóes nos diálogos ${ }^{15}$.

Procura-se deduzir toda a filosofia de Platão da oposição metafísica entre os Princípios Primeiros: o Princípio Uno, plasmando e produzindo unidade; o Princípio Díade, gerando a multiplicidade. Sistematiza-se Platáo em seus pontos centrais, interpretando o jogo, o mito e a ironia em suas referências aos ensinamentos orais.

\footnotetext{
Não há dúvida de que Platão tinha em mente apresentar uma visão unitária, capaz de abarcar o real na sua totalidade e nas suas partes. E, por mais incompletos que se mostrem, esses testemunhos nos permitem reconstruir os traços essenciais de tal "sistema" e os seus nexos fundamentais (Reale, 2004, p. 94).
}

Desse modo, ao reconstruírem o plano interno de cada diálogo e o plano geral de todos os diálogos em suas relações intrínsecas e em consonância com os “ensinamentos não-escritos" - que clarifica e fundamenta as passagens textuais obscuras -, poder-se-á reconstruir o verdadeiro "sistema” de Platão. É necessário, entretanto, diferenciar o paradigma hermenêutico da Escola de Tübingen e as interpretaçóes, muito diferentes, desenvolvidas pelos seus adeptos dentro das novas possibilidades de interpretação.

A reconstruçáo sistemática do platonismo a partir dos Princípios do Uno e da Díade caracteriza uma radical separação dualística do real e a sistematização hierárquica da realidade, que autores de linhas de interpretação diversas não aceitam em Platão, porque, nos diálogos subsequentes ao Parmênides, o ateniense procurava superar essa dicotomia radical (Cf. Trabattoni apud Perine, 2004, p. 28-29). A própria linguagem usada por Platão, que mesclava estruturas da escritura e da oralidade, é uma experiência que busca um meio pelo qual seja possível a transmissão de algum sistema ${ }^{16}$, mas sua "tecnologia" não era ainda suficiente para tanto. Segundo Havelock (1996),

muito da história da chamada filosofia grega dos primórdios não é uma história de sistemas de pensamento e sim a de uma busca de uma linguagem fundamental em que algum sistema pudesse exprimir-se [...] "o meio é a mensagem”, isto é, o conteúdo do

\footnotetext{
${ }^{15}$ Segundo a interpretação de Szlezák (2005, p. 29 ss), todos os diálogos, inclusive os primeiros, possuem remissões que pressupóe o socorro do lógos oral.

16 "Platão, à sua época, tentava mediar o combate agônico de duas potências que, a priori, pareciam antepor-se: a da oralidade - há muito impregnada na estrutura social e cultura dos helenos - e a da escrita, incipiente nas relaçóes humanas mas que já ocupava espaço considerável na Paidéia do homem grego” (Xavier, 2005, p. 195).
} 
que se comunica é regido pela tecnologia utilizada, mas também assevera que essa mesma tecnologia pode ter uma função causal na determinação do modo como pensamos (p. 16-17) ${ }^{17}$.

Somente com os filósofos posteriores, o discurso "conceitual" desenvolveu sua capacidade para transmitir e sistematizar o pensamento filosófico.

O novo paradigma encerra os diálogos em uma estrutura interpretativa pré-dialógica fundada nos "ensinamentos não-escritos", o que contraria frontalmente o ensinamento socrático de questionar o saber absoluto e contraria a própria estrutura da dialética platônica ${ }^{18}$. Por outro lado, possui o mérito de trazer à luz a importância dos "ensinamentos não-escritos" de Platáo e a necessidade de tê-los em consideração para uma adequada hermenêutica da filosofia platônica, mas não se pode diluir ou relegar para segundo plano a importância dos diálogos.

O debate acerca da importância e do alcance do novo paradigma e suas consequências na interpretação de Platão está em foco nos principais centros acadêmicos do mundo, mas, no Brasil, rigorosamente ainda não estáo acontecendo, apesar de nos últimos anos começarem a aparecer recessóes especializadas. Esperamos que as discussóes intensifiquem-se, afinal, o diálogo platônico é deveras rico e possui muitos tesouros ainda por descobrir.

\footnotetext{
${ }^{17}$ Hare (2004, p. 39-40) conjuga de posição semelhante.

${ }^{18}$ Cardoso (2006, p. 36-37). Para uma pormenorizada análise da dialética platônica, cf. Paviani (2001).
} 


\section{Referências}

ARISTOTE. Phisique I-IV. Texte Étable et traduit par Henri Carteron. Neuvième tirage. Paris: Les Belles Lettres, 2000, 1926. Texto grego à fronte.

ARISTÓTELES. Metafísica. Ensaio introdutório, texto grego com tradução e comentário de Giovanni Reale. Tradução para o português de Marcelo Perine. São Paulo: Loyola, 2002. Texto grego à fronte. v. 2-3.

CARDOSO, Delmar. A alma como centro do filosofar de Platão: uma leitura concêntrica do Fedro à luz da interpretação de Franco Trabattoni. São Paulo: Loyola, 2006.

GUTHRIE, W. K. C.. Historia de la filosofía griega. Madrid: Gredos, 1988. v. 4.

HARE, R. M. Platão. 2. ed. Tradução Adail U. Sobral e Maria S. Gonçalves. São Paulo: Loyola, 2004 .

HAVELOC, E. A. A revolução da escrita na Grécia e suas consequências culturais. Tradução Ordep José Serra. São Paulo: EdUNESP; Rio de Janeiro: Paz e Terra, 1996a.

ISNARDI PARENTE, M. Speusipo. Frammenti. Edizione, traduzione e commento. Nápoles: Bibliopolis, 1980.

- Senocrate-Ermodoro. Frammenti. Edizione, traduzione e commento. Nápoles: Bibliopoles, 1982.

JAEGER. Paidéia: a formação do homem grego. 4. ed. Tradução Artur M. Parreira. São Paulo: Martins Fontes, 2003.

KUHN, Thomas. A estrutura das revoluções cientificas. Tradução Beatriz Vianna Boeira e Nelson Boeira. São Paulo: Perspectiva, 1975.

MATTOS, Carlos Lopes. Doutrina. In: LOGOS: Enciclopédia Luso-Brasileira de Filosofia. [S. 1.]: [s. d.]. v. 1, p. 1464 .

PAVIANI, J. Filosofia e método em Platão. Porto Alegre: EdPUCRS, 2001.

PLATÃO. Diálogos: Fedro, Cartas, O primeiro Alcebíades. Tradução Carlos Alberto Nunes. Universidade Federal do Pará, 1975.

. Diálogos: sofista, político, Filebo. Timeu, Crítias. 2. ed. Tradução Maria G. de Bragança. Mira-Sintra: Europa-América, 1999. 
PLATO. The dialogues of Plato. 22. ed. Translated by Benjamin Jowett and J.Harward. ChigagoLondon-Toronto-Geneva-Sydney-Tokyo-Manila: Encyclopaedia Britannica, 1978.

PERINE, Marcelo. A tradição platônica indireta: de Aristóteles aos nossos dias. Phrónesis, v. 6, n. 2, jul./dez. 2004, Campinas. p. 11-31.

PLOTINUS. The six enneads. 22. ed. Translated by Stephen MacKenna and B. S. Page. Chigago-London-Toronto-Geneva-Sydney-Tokyo-Manila: Encyclopaedia Britannica, 1978.

REALE, Giovanni. História da filosofia antiga: Platão e Aristóteles. Tradução Marcelo Perine. São Paulo: Loyola, 1994. v. 2.

. Para uma nova interpretaçâa de Platão. Releitura da metafísica dos grandes diálogos à luz das "Doutrinas não-escritas". 2. ed. Tradução Marcelo Perine. São Paulo: Loyola, 2004.

SCHELEIERMACHER, F. D. E. Introdução aos diálogos de Platão. Traduçáo Georg Otte. Belo Horizonte: Ed. da UFMG, 2002.

VAZ, H. C. de Lima. Um novo Platão? Sintese nova fase, Belo Horizonte, v. 17, n. 50, p. 101113, jul./set. 1990.

WILAMOWITZ-MOLLENDORFF. Platon. Sein Leben und seine Werke. Berlim, 1919.

XAVIER, Dennys G. Para uma análise do critério schleiermacheriano de interpretação das obras de Platão. Educação e Filosofia, Uberlândia v. 19, n. 37, p. 179-199, jan./jun. 2005.

ZELLER, E. Die philosophie der griechen in ihrer geschichtlichen entwicklung. [S.1.], 1963. 